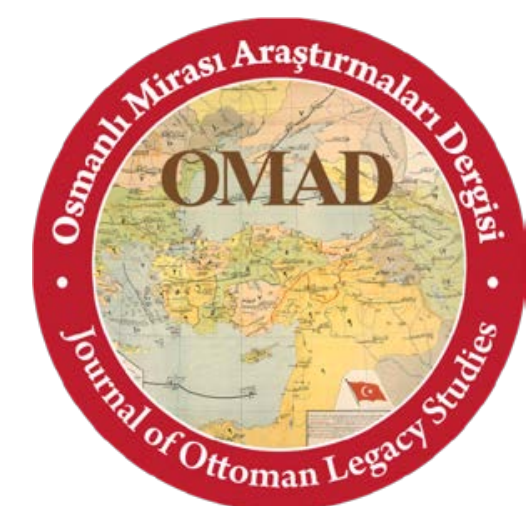

Osmanlı Mirası Araştırmaları Dergisi / Journal of Ottoman Legacy Studies

ISSN 2148-5704

www.osmanlimirasi.net

osmanlimirasi@gmail.com

Cilt 6, Sayı 14, Mart 2019 / Volume 6, Issue 14, March 2019

\title{
LEGAL REGULATIONS TO EQUALIZE THE CONDITIONS OF EMPLOYMENT INTO STATE OFFICIAL SERVICE IN OTTOMAN EMPIRE
}

Osmanlı Devleti'nde Memurluğa Giriş Şartların Eşitlemeyi Amaçlayan Hukuki

Düzenlemeler

\author{
Makale Türü/Article Types : Araştırma Makalesi/Research Article \\ Geliş Tarihi/Received Date : 19.01.2019 \\ Kabul Tarihi/Accepted Date : 28.02.2019 \\ Sayfa/Pages : 213-223 \\ DOI Numaras1/DOI Number : http://dx.doi.org/10.17822/omad.2019.120
}

\section{MEHMET AYKANAT}

(Dr. Öğr. Üyesi), Afyon Kocatepe Üniversitesi, Hukuk Fakültesi, Afyonkarahisar / Türkiye, email: mehmetaykanat@hotmail.com , ORCID: https://orcid.org/0000-0003-0968-4165

\section{$\underline{\text { Atıf/Citation }}$}

Aykanat, Mehmet, "Legal Regulations to Equalize the Conditions of Employment into State Official Service in Ottoman Empire", Osmanlı Mirası Araştırmalan Dergisi, 6/14, 2019, s.

213-223.

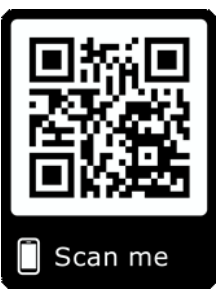





\title{
LEGAL REGULATIONS TO EQUALIZE THE CONDITIONS OF EMPLOYMENT INTO STATE OFFICIAL SERVICE IN OTTOMAN EMPIRE
}

\author{
Osmanlı Devleti’nde Memurluğa Giriş Şartlarını Eşitlemeyi Amaçlayan Hukuki \\ Düzenlemeler
}

\section{MEHMET AYKANAT}

\begin{abstract}
In the classical period, the Ottoman Empire created a unique state official system. In this system, non-Muslim citizens were not given equality in state official systems. However, in the Tanzimat period the Empire tried to achieve this equality for various reasons. Equality provisions are included in the constitution, constitutional documents and various laws. The legal regulations of the Ottoman Empire aiming to provide equality in access to the state official employment are not examined. The contents of these legal regulations have not been adequately evaluated in terms of access to the state official employment. The principles and conditions of employment have not been compared with today's regulations. The studies are mostly concentrated in the field of application and the theoretical part of the subject is omitted. This study sets out the basic legal arrangements aimed at equalizing the employment requirements for the state officials. These regulations appear to be sufficient in terms of the principles and conditions of employment of state officials. It is understood that the Ottoman Empire established the system of employment into the modern state official position with these regulations.
\end{abstract}

Keywords: Official service, equality, Ottoman law, Ottoman Constitution

Öz: Osmanlı Devleti, klasik dönemde kendine özgü bir memur sistemi oluşturmuştur. Bu sistemde, memurluğa girme konusunda gayrimüslim vatandaşlarına eşitlik sağlayamamıştır. Ancak Tanzimat döneminde, çeşitli sebeplerle bu eşitliği sağlamaya çalışmıştır. Eşitlik sağlayıcı hükümler, anayasada, anayasal belgelerde ve çeşitli kanunlarda yer almıştır. Osmanlı Devleti'nin memurluğa girişte eşitlik sağlamayı amaçlayan hukuki düzenlemeleri, yeterince incelenmiş değildir. Bu hukuki düzenlemelerin içerikleri, memurluğa giriş açısından yeterli şekilde değerlendirilmemiştir. Memurluğa giriş ilkeleri ve şartları, günümüz düzenlemeleri ile karşılaştırılmamıştır. Çalışmalar daha çok uygulama alanında yoğunlaşmış, konunun teorik kısmı atlanmıştır. Bu çalışma, memurluğa giriş şartlarını eşitlemeyi amaçlayan temel hukuki düzenlemeleri ortaya koymaktadır. Bu düzenlemeler, memurluğa giriş ilkeleri ve şartları bakımından yeterli görünmektedir. Osmanlı Devleti’nin bu düzenlemeler ile modern memurluğa giriş sistemini kurduğu anlaşılmaktadır.

Anahtar Kelimeler: Memur hukuku, memurluğa giriş şartları, eşitlik, Osmanlı hukuku, Osmanlı anayasası

\section{Introduction}

In the Ottoman literature, the state official was defined as the mass of the people involved in the state activities. ${ }^{1}$ As States consider their activities important, they thought of employment into state official service with utmost importance. With the commencement of the enactment, the conditions for employment in the state official position took place in the legal regulations.

Countries have had various principles and conditions for employment in state official position. In the classical period in which Islamic Code was applied, the Ottoman Empire determined these principles and conditions according to Islamic Code. In the Tanzimat period (eng. Imperial Edict of Reorganizations), the principles and conditions started to be regulated in

\footnotetext{
${ }^{1}$ Celaleddin Arif, Hukuk-ı Esasiye, Ahmed Saki Bey Matbaası, İstanbul 1325, p. 158.
} 
the laws. With the foundation of the Constitution, it is seen that these principles and conditions are included in the Constitution.

There are three principles on employment such as freedom, equality and not searching for any other requirements than required for the task. ${ }^{2}$ It is understood that the Ottoman Empire could not implement these principles in the classical period due to various reasons. Since the state officials were selected among those who grew up in Enderun (special school in the Ottoman palace), the concept of equality was naturally limited. ${ }^{3}$ In the post-classical period, it was attempted to ensure equality in the employment to the office.

Kemalpasazade Said, in the classical period of the Ottoman Empire, claimed that he had provided equality in some cases; however, he had failed to provide equality in the employment to office. ${ }^{4}$ Bozkurt stated that the most important restriction on non-Muslims was that they could not be employed in state official service. ${ }^{5}$ Konan stated that they were granted manors from the conquered land; zimmis (eng. Non-muslim subject in the ottoman empire) were appointed to some duties such as chamberlain and voivodeship. ${ }^{6}$ In the classical period, it is known that non-Muslims worked in interpreting missions. ${ }^{7}$

The post-classical period was a period in which the state official system of the Ottoman Empire changed. These amendments were supported by legal arrangements. The roots of our state personnel regime are based on the regulations made in this period. This reveals the importance of the Tanzimat legal regulations. Legal capacity and merit system was established for the state official employment. ${ }^{8}$ Another importance of the regulations in this period is that they establish a western type of office for the first time. ${ }^{9}$

Arrangements that change the state official system of the Ottoman Empire and form the basis of the modern system have not been adequately addressed. Although there are studies aimed at implementation, the theory of these regulations was not put forward. In the Tanzimat period, the Ottoman Empire established an employment of state official system very similar to today's Code. The basic principles and conditions adopted today have been included in the legal regulations.

\section{Legal Regulations}

There are three important constitutional documents in the Ottoman Empire prior to the constitution. In the first two of these documents, there are no provisions for state official employment. The Sened-i Ittifak (eng. Charter of Alliance), which is considered the first constitutional document, does not contain a provision regarding state official employment or equality. ${ }^{10}$ The Tanzimat Edict, which was adopted for the first time in terms of rights, did not include a provision for state official employment. ${ }^{11}$ The Tanzimat Edict is an arrangement concerning our subject in terms of equality efforts. It is understood that it affects the conditions of state official employment.

\footnotetext{
${ }^{2}$ Kemal Gözler and Gürsel Kaplan, İdare Hukuku Dersleri, Ekin, Bursa 2015, pp. 633-34.

${ }^{3}$ Birgül Ayman Güler, Kamu Personeli: Sistem ve Yönetim, İmge, Ankara 2005, p. 144.

${ }_{5}^{4}$ Kemalpaşazade Said, Hukuk- Siyasiye-i Osmaniye, Alemdar Matbaası, İstanbul 1329, p. 47 ed seq.

${ }^{5}$ Gülnihal Bozkurt, "Türk Hukuk Tarihinde Azınlıklar," Ankara Üniversitesi Hukuk Fakültesi Dergisi, Volume: 43, Issue: 1-4, 1993, p. 51.

${ }^{6}$ Belkıs Konan, "Gayrimüslim Osmanlı Vatandaşlarının Hukuki Durumuna İlişkin Bir Değerlendirme," Ankara Üniversitesi Hukuk Fakültesi Dergisi, Volume: 64, Issue: 1, 2015, p. 184.

${ }^{7}$ Sevilay Kasap, “Osmanlı Merkez Bürokrasisinde Gayrimüslimlerin İstihdamı, (1839-1876)”, Yayımlanmamış DT, Marmara Üniversitesi, SBE, İstanbul 2011, p. 221.

${ }^{8}$ Güler, Kamu Personeli: Sistem ve Yönetim, pp. 157-58.

${ }^{9}$ Onur Ender Aslan, Kamu Personel Hukuku, Anadolu Üniversitesi, Eskişehir 2012, p. 21 ed seq.

${ }^{10}$ For the text, please see Burhan Kuzu, Türk Anayasa Metinleri ve İlgili Mevzuat, Filiz, İstanbul 1988; Ali Aky1ldız, “Sened-i İttifak'ın İlk Tam Metni," Íslam Araştırmaları Dergisi, Issue: 2, 1998.

${ }^{11}$ For the text, please see "Gülhane Hatt-1 Hümayunu," in Düstur 1/1, Matbaa-i Amire, İstanbul 1839, 4 ed seq.
} 
The Reform Edict of 1856 introduced very important provisions concerning the right to be employed into public services. According to this, all citizens of the Ottoman Empire, regardless of nationality, will be able to be employed by public services. According to the legal capacity and merit, in the framework of general provisions employment will be provided in the public service. ${ }^{12}$ The Islahat Edict aimed at transforming the administration into a wider and participatory structure. ${ }^{13}$ It is seen that the regulations in the Islahat Edict increased non-Muslim employment in practice. ${ }^{14}$ The Islahat Edict can be regarded as the most important arrangement that provides equality under the conditions of state official employment. It is a turning point in the entry of non-Muslim citizens into the civil service.

With the foundation of the Constitution, regulations of state official employment has gained a constitutional status. Article 8 of the Ottoman Constitution defines citizenship. It was regulated that regardless of religion and sect, the people subject to Ottoman Empire was the Ottoman people. Article 17 of the Constitution states that all Ottomans are equal before the law. Article 19 of the Constitution states that all citizens can employ in the appropriate state official position in accordance with their competence and skills. It is stated in Article 18 of the Constitution that it is necessary to have command in Turkish. Article 39 states that the conditions for being employed into office shall be determined by Code.

The conditions of state official employment mentioned in Article 39 of the Constitution are regulated by Code. In the 1880s, Guler mentioned the establishment of a system of merit. ${ }^{15}$ Memurin-i Mülkiye Terakki ve Tekaüd Kararnamesi (Eng. Decree of State Official Prosecution, Development and Retirement Code) has included conditions of state official employment. The first three articles of this law relate to the conditions of state official employment. ${ }^{16}$ Another Code regulating the appointment of judicial officers and judges includes the conditions for the employment of these state officials into the civil services.

\section{Principles for Employment of State Official Service}

There are three basic principles in the process of employment into the state official service. These are the principle of freedom, the Principle of Equality and the principle of not seeking qualifications other than the qualifications required by the task. ${ }^{17}$ Aslan adds state official is right to Turkish citizens to these principles, which he expresses as constitutional principles. ${ }^{18}$ Avci added the principle of legality. ${ }^{19}$

\subsection{Principle of Freedom and Prohibition of Drudgery}

The principle of Freedom of employment into state official service refers to the choice as he / she wants it or not. In the rights and freedoms section of the Ottoman Constitution, Prohibition of Drudgery was regulated. Article 24 of the Constitution prohibits the Drudgery.

In the Ottoman legal regulations, there were generally no provisions against the Principle of Freedom. However, it is observed that measures are taken to guide people to work. For example, because the newly graduated doctors do not want to work in the provinces, a law has been prepared about the measures that will enable them to be employed as state official. The law of 1888 envisaged measures to force physicians, such as taking bills at the beginning of

\footnotetext{
${ }^{12}$ For the text, please see "Islahat Ferman1," in Düstur 1/1, Matbaa-i Amire, İstanbul 1856, 7-14.

13 Ercan Uyanık, "Tanzimat Dönemi’nde (1839-1876) Yönetim Yapıs1," in Türk İdare Tarihi, ed. Erkan Tural, Anadolu Üniversitesi, Eskişehir 2013, p. 116.

${ }^{14}$ Kasap, ibid, p. 222.

${ }^{15}$ Güler, ibid, p. 159.

${ }^{16}$ Düstur Zeyl 3, “Memurin-i Mülkiye Terakki ve Tekaüd Kararnamesi,” 1881, p. 62.

${ }^{17}$ Gözler and Kaplan, ibid, pp. 633-34.

${ }_{18}^{18}$ Aslan, ibid, pp. 48-49.

${ }^{19}$ Mustafa Avcı, "Devlet Memurları Kanunu Kapsamında Kamu Görevliliğine Giriş”, Yayımlanmamış DT, Anadolu Üniversitesi, SBE, Eskişehir 2009, p. 34 ed seq.
} 
school, not being assigned to the city centers, and demanding some fees. In correspondence, it is mentioned that there is no law that will force these people to work. ${ }^{20}$ It is obvious that there is a similar issue about a similar problem for the graduates of Imperial Civil School It is mentioned that graduates do not want to work in rural areas and the measures are emphasized accordingly. ${ }^{21}$ In fact, the aforementioned regulations show that there is freedom of employment as state official. In the examples, it is seen that people do not want to work especially in rural areas and remote areas. Laws are regulated not to force people, but to guide them.

\subsection{Principle of Equality}

In the Ottoman literature, the word equality was used as meaning of "balance". The word meaning of "being equal" means that "one person is not superior to the other". ${ }^{22}$ Hamid stated that the equality was repeated by the Tanzimat and Islahat, as guaranteed by Islamic law, and was once again registered with the Law. ${ }^{23}$

In the classical period, one of the issues that the Ottoman Empire could not achieve to equalize was employment into the state official service. During this period, non-Muslims could not be employed as state officials. However, Islamic law has adopted the principle that "the most auspicious of people, it is people who are useful" and "one who is lord of the people, is the one who serves" Assignment of persons who will be useful is in accordance with Islamic law. The state has not been able to overcome this inequality due to its circumstances. ${ }^{24}$

Although there is no provision regarding the employment into state official service in the Tanzimat Edict, it is understood that it has an effect on the employment of non-Muslim citizens into the state official service due to the equality concept. Post-Tanzimat bureaucratic reforms and the number of non-Muslim state officials increased in practice. The items in connection with the High Porte were converted into ministries during this period. The newly established ministries, especially the Ministry of Foreign Affairs, were the institutions where non-Muslim citizens were employed to the state official service. ${ }^{25}$

The Edict of Islahat (eng. Edict of Reform) arranged the right of all citizens to employment into the state official service regardless of religion. ${ }^{26}$ The entry of the non-Muslims to the state official increased with the Reform Edict and the period of Abdülhamit II was the period when non-Muslims were the most heavily recruited. ${ }^{27}$

The Principle of Equality has become a constitutional principle after being included in various legal documents and regulated in the Ottoman Constitution. ${ }^{28}$ The principle of equality is regulated in Article 17 of the Ottoman Constitution. In this article, it is stated that all of the Ottomans are equal before the law, except in the case of religion and sect, in terms of rights and

${ }^{20}$ Düstur 1/6, "Mekteb-i Mülkiye-i Şahaneden Neşet Edipte Taşra Memuriyetini Kabulden İstinkaf Edenler Hakkında Olunacak Muameleye Dair Nizamname”, Devlet Matbaas1, Ankara 1893, pp. 1406-7.

21 Düstur 1/8, "Mekteb-i Mülkiye-i Şahane Mezunlarının Maiyet Memuriyetleriyle Kaza Kaymakamlıklarına Tayinleri Emrinde Müttehaz Usul Hakkında İrade-i Seniye”, Başvekalet Devlet Matbaası, Ankara 1905, p. 200 ed seq.

${ }^{22}$ Yusuf Açıkel, "Hz. Peygamber'in Evrensel Mesajlarından 'Müsavat,”' in IV. Kutlu Doğum Sempozyumu, SDÜ İlahiyat Fakültesi, 2001, pp. 416-18.

${ }^{23}$ Hamid, Hukuk-ı Esasiye ve İdare Dersleri, Matbaa-i Amire, İstanbul 1331, p. 43.

${ }^{24}$ Kemalpaşazade Said, ibid, p. 53.

${ }^{25}$ Musa Kılıç, "Tanzimat Döneminde Osmanlı Hariciye Nezareti'nin Ermeni Memurları," Ankara Üniversitesi Dil ve Tarih-Coğrafya Fakültesi Tarih Bölümü Tarih Araştırmaları Dergisi, Volume: 31, Issue: 51, 2012, p. 94 ed seq.

${ }^{26}$ Yavuz Abadan, "Osmanlı İmparatorluğunda Anayasa Sistemine Geçiş Hareketleri," Ankara Üniversitesi Hukuk Fakültesi Dergisi, Volume: 14, Issue: 1, 1943, p. 15. Bülent Tanör, Osmanll-Türk Anayasal Gelişmeleri, 17891980, Yap1 Kredi, İstanbul 2017, p. 96. Konan, ibid, p. 186.

27 Abdülhamit Kırmızı, "Osmanlıcılık Bürokrasisinde Gayrimüslim İstihdamı,” Divan İlmi Araştırmalar, Issue: 13, 2002, p. 301 ed seq.

${ }^{28}$ Nevin Ünal Özkorkut, “1876 Anayasası'nın Hukuk Devleti Unsurları Açısından Osmanlı Devlet Anlayışına Getirdiği Yenilikler,” Ankara Üniversitesi Hukuk Fakültesi Dergisi, Volume: 53, Issue: 1, 2004, p. 177. 
duties. Articles 19 and 39 of the Constitution concerning employment into the state official service are related to equality.

Constitutional regulation has undoubtedly affected the laws. No one's origin, religious opinion, philosophical thought, profession, political opinion should be taken into account in state official employment. Any law that does not comply with this principle shall be contrary to the Principle of Equality and will be contrary to fundamental rights and freedoms. ${ }^{29}$

The Ottoman Empire has created practices to implement legal regulations. In accordance with the provisions of Islahat, in the Ioannina division, it has been reported that the equality of the population distribution in the appointment of state officials should be ensured. ${ }^{30}$ It is understood that other states followed the recruitment of state officials of the Ottoman Empire. ${ }^{31}$

Although equality of non-Muslims is emphasized, the Principle of Equality is a principle that concerns all citizens. In the state official employment, it is necessary not only to discriminate against religion but also to make different distinctions. It is seen that the Ottoman Empire provided the Principle of Equality in legal regulations.

\subsection{Not Seeking Qualifications Other Than the Qualifications Required by the Task}

In today's law, the search for the qualities required by the task is not seen as contrary to the Principle of Equality. In the Ottoman laws, the regulations related to be tasked in civil service were arranged. It has been arranged that four questions will be asked from Mecelle (eng. Ottoman Code of Civil Law) and other laws applied in the entrance examination of the judicial officers. ${ }^{32}$ In the regulation concerning the directorates of education, the requirements were high school graduation and working conditions for at least five years and ability of accounting. ${ }^{33}$ In the law prepared to be added to the state officials law, the conditions for employment to the responsible clerkship were regulated. These conditions are to have fulfilled certain tasks before. Those who did not carry out these tasks are claimed to be skilled and cannot be assigned to the task. ${ }^{34}$ The important thing is not looking for qualifications that are not related to the task.

Article 19 of the Constitution provides that citizens will be recruited in accordance with their qualifications and abilities. This eligibility must be the qualifications required by the task. No other regulation directly prohibited the search for qualifications other than the qualifications required by the task.

\section{Conditions for Employment of State Official Service}

The conditions of employment into the office are the most important issue to ensure equality. The conditions in the Ottoman Empire took place at the Constitutional level. The Ottoman Constitution included provisions on employment requirements for civil service. The conditions for employment into the civil service are regulated in various laws. Article 2 of the Act of 1888 about the appointment of judges and other judicial officers regulates whether the candidates meet the requirements in the law and that they will be controlled by the registry manager or not. ${ }^{35}$

\footnotetext{
${ }^{29}$ Celaleddin Arif, Hukuk-ı Esasiye, Darülhalife Matbaas1, İstanbul 1329, pp. 101-2. Hamid, ibid, p. 45.

${ }^{30}$ Prime Ministerial Ottoman Archive (BOA), Interior Ministry Office of Encoding Documents (DH.ŞFR), 219/53, 26.12.1897.

${ }^{31}$ Prime Ministerial Ottoman Archive (BOA), Foreign Ministry's Translation Bureau (HR.TO), 165/76, 20.11.1895.

32 Düstur 1/5, "Hükkam Vesair Memurin-i Adliyenin Usulü İntihab ve Tayinlerine Dair Kanun”, Başvekalet Matbaas1, Ankara 1888, p. 1060.

${ }^{33}$ Düstur 1/6, "Kaza Kaymakamlariyla Nahiye ve Tahrirat Müdürlerinin İntihab ve Tayinine Memur Komisyonun Vazifesine Dair Nizamname", Devlet Matbaası, Ankara 1888, p. 226.

34 Düstur 1/6, "Usul-i İntihab-1 Memurin-i Adliye Kanununa Tezyil Edilmek Üzere Kaleme Alınan Mevaddı Kanuniye," 1893, pp. 1367-68.

${ }^{35}$ Düstur 1/5, “Hükkam Vesair Memurin,” p. 1058.
} 
The first part of the Law on Prosecution of State Officials (TR: Memurîn-i Mülkiye Terakki ve Tekaüd Kararnâmesi) regulates the issues of employment, promotion and dismissal of state officials. ${ }^{36}$ In the $1^{\text {st }}$ Article of this Code, to be an Ottoman citizen, to be no younger than twenty years old, well-mannered, one has the special skills required for the state official service and to be able to prove that with graduation document and with the interview held by the commission. The third article states that the sentence of one year or more imprisonment impedes state officials.

As a result, the Constitutional conditions of employment into state officials in the Ottoman Empire, were being a citizen of the Ottoman Empire, competent in Turkish and capable of doing the required tasks in the job. Conditions such as being regulated by laws, being at least twenty years old, and not being sentenced to more than a year of imprisonment should be added. The conditions of not having a bond with the military and not having a health problem that prevented them from taking office are not included in the Ottoman legal regulations.

\subsection{Being an Ottoman Citizen}

The Ottoman Constitution stipulated the requirement of being a citizen for employment into the civil service in the Article 19 with the words of "all citizens" In Article 18 which regulates the requirement of being potent in Turkish, there is a clause of "Ottoman citizens" In Article 17 on the Principle of Equality, the phrase of "all Ottomans" was preferred. In contrast to the provisions of the Constitution, it is understood that foreigners cannot be state officials. In the Constitution, no requirement is required for Ottoman citizens other than command in Turkish. The requirement to become a citizen is an arrangement that allows non-Muslim citizens to be state officials.

Providing that foreigners are to be employed in some tasks, it was stated that this were possible with the Sultan's will. ${ }^{37}$ A similar provision was included Memurin-i Mülkiye Terakki ve Tekaüd Kararnamesi (Eng. Decree of State Official Prosecution, Development and Retirement Code). Article 2 of this Code regulates that foreigners may become state officials with the Sultan's will. It is understood from the Registry that foreigners were assigned to the Ministry of Foreign Affairs. ${ }^{38}$ The appointment of foreign ministry officials in some tasks was seen as objectionable. ${ }^{39}$

In an imperial decree of a year of 1889, the procedure for the prosecution of foreign officials was specified. It was recalled that the mentioned procedure was to be written on the contracts made with foreigners. ${ }^{40}$ It is understood from this will that foreigners entered the contract with a contract.

Being an Ottoman citizen is a condition for employment into the office in the Constitution and Laws. However, it is understood that there are exceptions to this general rule. Foreigners were able to work in government offices with a Will of the Sultan.

\subsection{Command in Turkish}

Article 18 of the Ottoman Constitution states that citizens who work as state official are required to have excellent command in Turkish, which is the official language of the state. This regulation was discussed in terms of the Principle of Equality. According to Celaleddin Arif and

\footnotetext{
${ }^{36}$ Düstur Zeyl 3, “Memurin-i Mülkiye,” 62.

${ }^{37}$ Ahmed Şuayb, Hukuk-ı İdare Birinci Kısım, Hürriyet Matbaası, İstanbul 1328, p. 449. İbrahim Hakkı, Hukuk-ı İdare, Karabet Matbaası, İstanbul 1312, p. 209.

${ }^{38}$ Prime Ministerial Ottoman Archive (BOA), Foreign Ministry Political Affairs (HR.SYS), 2926/5, 14.11.1852.

${ }^{39}$ Prime Ministerial Ottoman Archive (BOA), Yıldız Palace General Documents (Y.PRK.UM), 35/55, 11.8.1896.

40 Düstur 1/6, "Devlet-i Aliye Hizmetinde Bulunan Ecnebilerin Umuru Memurelerinden Dolayı Merci Muhakemelerile Hini İstihdamlarında Mukavelelerine Dercedilecek Kayıd Hakkında İrade-i Seniye”, Devlet Matbaas1, Ankara 1889, p. 393.
} 
Hamid, the requirement of command in Turkish in Article 18 of the Constitution is not an exception to the equality provision. Because the official language of the Ottoman Empire is Turkish, and all official correspondence is done in Turkish. For this reason, it will not be possible of tasks to to be performed by non-Turkish speakers, process will be interrupted. ${ }^{41}$

Omer Ziyaeddin has linked the requirement of command in Turkish to being competent. He stated that the person who does not speak and write in Turkish will not be competent as a state official. It has also established links with the Mecelle (eng. Ottoman Code of Civil Law), which regulates the qualifications of judges. This article states that the judge should have a high quality of comprehension and that the same qualification should be in the officials. To be able to comprehend, the command in Turkish is necessary. ${ }^{42}$ Before the Constitution, there are documents indicating the need for the Turkish-speaking officer. ${ }^{43}$

In the Code which regulates the conditions for employment in the governorship, the existence of Turkish writing ability has been added again. ${ }^{44}$ It is understood that such a provision is made since Turkish writing requires more expertise than Turkish speaking. Christian citizens who have equal conditions at the time of employment of the state official have been identified as having better education opportunities and it has been determined that Christian citizens have become advantageous from the Reform Edict. It has been suggested that the requirement of speaking Turkish to prevent Christians from coming to high ranks. ${ }^{45}$

Speaking Turkish is not only a constitutional requirement, but also an element of merit. In practice, non-Muslim officials were removed from the bureaucracy because they had inadequate command in Turkish. ${ }^{46}$ In the town of Kesendire, police officers were taken off duty because they had inadequate command in Turkish. ${ }^{47}$

Nowadays, it is required to speak foreign languages in employment of state official positions. However, the requirement of speaking Turkish is not in the regulations. The requirement of speaking Turkish is a result of the Ottoman social structure. It is not intended to use the exams for eliminatione of those who do not speak Turkish. It is understood that such a provision is put in order due to the political conjuncture of the period.

\subsection{Legal Capacity and Merit}

Legal capacity is to have rights, to do tasks and take responsibility. ${ }^{48}$ Merit is the eligibility of a person to be employed. ${ }^{49}$ Article 19 of the Ottoman Constitution regulates that all citizens can be employed as state official according to legal capacity and abilities. As legal capacity and ability are proved by graduation documents, they include a learning requirement.

In relation to article 19 of the Constitution, Ömer Ziyaeddin explained the order of the Koran as "to assign those who were competent" and explained that a Christian who was

\footnotetext{
${ }^{41}$ Celaleddin Arif, Hukuk-ı Esasiye, 1329, pp. 101-2. Hamid, ibid, p. 45.

${ }^{42}$ Ömer Ziyaeddin, Mirat-ı Kanun-ı Esasi, Saika Matbaası, İstanbul 1324, p. 37.

${ }^{43}$ It was important for the communication officers to have command in Turkish. It has been recorded in the records that Turkish-speaking officers should be taken to the telegraph houses established in places such as Chios, Crete, Çeşme and Midilli where non-Muslim population are densely populated. Prime Ministerial Ottoman Archive (BOA), Sadaret (Prime Ministry) All Provinces Documents (A.MKT.UM), 557/38, 22.4.1862.

${ }^{44}$ Düstur 1/6, "Kaza Kaymakamları," p. 226.

45 Gürsoy Akça and Himmet Hülür, "Osmanlı Hukukunun Temelleri ve Tanzimat Dönemindeki Hukuksal Yeniliklerin Sosyo-Politik Dinamikleri,” Selçuk Üniversitesi Türkiyat Araştırmaları Dergisi, Issue: 19, 2006, p. 310.

${ }^{46}$ Kasap, ibid, p. 222.

${ }^{47}$ Prime Ministerial Ottoman Archive (BOA), Police and Security Documents (ZB), 112/4, 2.9.1890.

${ }^{48}$ Türk Hukuk Lugati, Türk Hukuk Kurumu, Ankara 1991, p. 81.

49 "Liyakat," Türk Dil Kurumu Büyük Türkçe Sözlük, accessed February 12, 2019, http://www.tdk.gov.tr/index.php?option=com_bts\&arama=kelime\&guid=TDK.GTS.5c6325069d50b1.46513730. About liyakat see, Kübra İmran Diler, "Kamu Personel Hukukunda Liyakat İlkesi”, Yayımlanmamış YLT, Ankara Üniversitesi, SBE, Ankara 2018.
} 
removed from his duty in the Ka'bah was sent back to his duty for reinstatement. ${ }^{50}$ There were state officials who were dismissed because they were not qualified before the legal regulations. ${ }^{51}$ Non-Muslims in Ottoman practice were preferred because of their merit. Especially in institutions that speaking foreign languages is a requirement, non-Muslim citizen employed in state official position. ${ }^{52}$

In the Constitution there was a statement of competence and ability; but the details were not arranged. A related Law stipulated that the legal capacity and ability required by the state official service should be proved by graduation certificate and examination. ${ }^{53}$ It has been stated that even the interns should have minimum high school diploma. ${ }^{54}$ However, in another Law, it is clear that experience is the requirement instead of graduation. The conditions for employment in the district governor's office included either the requirement for high school graduation or working for five years. ${ }^{55}$

It is obvious that commissions were established to determine the legal capacity and merit. In 1896, the Commission on State Officials was established as a central commission to carry out various tasks, including employment into the state official service. Apart from that, various commissions are included in the legal regulations. The Law on how to set up a commission for judicial officers is regulated. Article 8 of the Code stipulates that three out of the five members of the commission will be elected from high-ranking state officials, two of them from the Faculty of Code ${ }^{56}$ In another Code, the formation and operation of the commission, which will appoint the district governors and sub-district directorates. There is a provision for half of the members of the Commission to change every six months. ${ }^{57}$ Similar provisions have been included in the Code on the appointment of tax officers. It is organized how the Commission will be formed and will work. ${ }^{58}$

Legal capacity and merit can be regarded as the requirement for entry into the most important office. While other conditions are mostly related to non-Muslim citizens, legal capacity and merit concern all citizens. It is seen that the Ottomans made legal regulations regarding the legal capacity and merit. The provisions of the examination and determination of the legal capacity and merit with the documents have been predominantly included in the regulations.

\subsection{Minimum Age Limit}

Ahmed Suayb stated that the requirement of employment in state official service was to be at least twenty years old; however, he stated that he had started working before the age of twenty. He stated that the periods before the age of twenty as a sanction were not taken into account in the retirement account. ${ }^{59}$ There are similar regulations in the Code. In the regulation on the retirement of state officials working in the military departments, it is planned that their

\footnotetext{
${ }^{50}$ Ömer Ziyaeddin, ibid, pp. 37-38.

${ }^{51}$ Prime Ministerial Ottoman Archive (BOA), Cevdet Health Documents (C.SH), 25/1202, 4.3.1840.

${ }^{52}$ Kasap, ibid, p. 221.

${ }^{53}$ Düstur Zeyl 3, “Memurin-i Mülkiye,” p. 62.

${ }^{54}$ İbrahim Hakk1, ibid, p. 209.

${ }^{55}$ Düstur 1/6, "Kaza Kaymakamları”, p. 226.

${ }^{56}$ Düstur 1/5, "Hükkam Vesair Memurin”, p. 1059.

${ }^{57}$ Düstur 1/6, "Kaza Kaymakamlar1,”, p. 224.

58 Düstur 1/8, "Memurin-i Rüsumiyenin Usulü İntihabiyesi Hakkında Nizamname”, Başvekalet Devlet Matbaası, Ankara 1906, p. 431 ed seq.

${ }^{59}$ Ahmed Şuayb, ibid, p. 449.
} 
services will be started from the age of twenty. ${ }^{60}$ In the Ottoman documents, it is seen that the knowledge of the study is requested after the age of 20 years. ${ }^{61}$

İbrahim Hakki informed that it is enough for the trainees to be sixteen years old and stated that they would not be eligible for the salary before the age of twenty ${ }^{62}$ As can be seen, the age requirement in the regulations is related to the minimum age. There is no limit for max age.

\subsection{Not Having a Conviction Over a Specific Time}

The condition of not being condemned at the employment of state officials has been arranged in more detail today. In the Ottoman Empire, in the third article of the Decree of State Officials Progress and Proclamation, one year or more imprisonment was accepted as a trammel. In the regulations of the Ottoman Code, there has been no regulation on conviction for certain types of crime.

\section{Conclusion}

The Ottoman State, along with the Tanzimat period, reorganized the employment system to the state official services. Ottomans tried to eliminate the inequalities in the classical period with the legal arrangements. Thus, legally, a system of entry into the state officials of all Ottoman citizens was established. So, which regulations did provide these equalities?

The Ottoman State has made the first legal arrangements which are the basis of our modern state official system. However, with the details of these regulations, the research was insufficient. Did the Ottoman Constitution and its laws set out the principles and conditions of employment into the state official system? Were the arrangements enough? The first regulations on the conditions of entry to the civil service include provisions similar to the laws of today.

The Ottoman doctrine discussed the reasons for which the provisions were made. These discussions will shed light on the present and reveal the reasons for the laws. The Ottoman Constitution and its laws included all principles and conditions that would ensure equality in access to the office. According to the period, provisions that can be deemed to be quite advanced.

\section{Bibliography}

“Liyakat.”, Türk Dil Kurumu Büyük Türkçe Sözlük, Accessed February 12, 2019. http://www.tdk.gov.tr/index.php?option=com_bts\&arama=kelime\&guid=TDK.GTS.5c632 5069d50b1.46513730.

Abadan, Yavuz, "Osmanlı İmparatorluğunda Anayasa Sistemine Geçiş Hareketleri”, Ankara Üniversitesi Hukuk Fakültesi Dergisi, Volume: 14, Issue: 1, 1943, pp. 3-37.

Açıkel, Yusuf, "Hz. Peygamber'in Evrensel Mesajlarından 'Müsavat"” in IV. Kutlu Doğum Sempozyuтu, SDÜ İlahiyat Fakültesi, 2001, pp. 415-439.

Ahmed Şuayb, Hukuk-ı İdare Birinci Kısım, Hürriyet Matbaası, İstanbul 1328.

Akça, Gürsoy, and Himmet Hülür, "Osmanlı Hukukunun Temelleri ve Tanzimat Dönemindeki Hukuksal Yeniliklerin Sosyo-Politik Dinamikleri”, Selçuk Üniversitesi Türkiyat Araştırmaları Dergisi, Issue: 19, 2006, pp. 295-321.

60 Düstur 1/6, “Devair-i Askeriyede Müstahdem Memurin ve Ketebe-i Mülkiye Tekaüd Nizamnamesi”, Devlet Matbaası, Ankara 1888, p. 46.

${ }^{61}$ Prime Ministerial Ottoman Archive (BOA), Interior Ministry Correspondence Office (DH.MKT), 2425/121, 7.11.1900.

62 İbrahim Hakkı, ibid, p. 209. 
Akyıldız, Ali, “Sened-i İttifak’ın İlk Tam Metni”, İslam Araştırmaları Dergisi, Issue: 2, 1998.

Aslan, Onur Ender, Kamu Personel Hukuku, Anadolu Üniversitesi, Eskişehir 2012.

Avcı, Mustafa, "Devlet Memurları Kanunu Kapsamında Kamu Görevliliğine Giriş", Yayımlanmamış DT, Anadolu Üniversitesi, SBE, Eskişehir 2009.

Bozkurt, Gülnihal, “Türk Hukuk Tarihinde Azınlıklar”, Ankara Üniversitesi Hukuk Fakültesi Dergisi Volume: 43, Issue: 1-4, 1993, pp. 49-59.

Celaleddin Arif, Hukuk-ı Esasiye, Ahmed Saki Bey Matbaası, İstanbul 1325.

Celaleddin Arif, Hukuk-ı Esasiye, Darülhalife Matbaası, İstanbul 1329.

Diler, Kübra İmran, "Kamu Personel Hukukunda Liyakat İlkesi”, Yayımlanmamış YLT, Ankara Üniversitesi, SBE, Ankara 2018.

Düstur 1/1, “Gülhane Hatt-1 Hümayunu”, Matbaa-i Amire, İstanbul 1839, pp. 4-7.

Düstur 1/1, "Islahat Fermanı”, Matbaa-i Amire, İstanbul 1856, pp. 7-14.

Düstur 1/5, "Hükkam Vesair Memurin-i Adliyenin Usulü İntihab ve Tayinlerine Dair Kanun", Başvekalet Matbaası, Ankara 1888.

Düstur 1/6, "Devair-i Askeriyede Müstahdem Memurin ve Ketebe-i Mülkiye Tekaüd Nizamnamesi”, Devlet Matbaası, Ankara 1888, pp. 46-55.

Düstur 1/6, "Devlet-i Aliye Hizmetinde Bulunan Ecnebilerin Umuru Memurelerinden Dolay1 Merci Muhakemelerile Hini İstihdamlarında Mukavelelerine Dercedilecek Kayıd Hakkında İrade-i Seniye", Devlet Matbaası, Ankara 1889.

Düstur 1/6, "Kaza Kaymakamlarıyla Nahiye ve Tahrirat Müdürlerinin İntihab ve Tayinine Memur Komisyonun Vazifesine Dair Nizamname”, Devlet Matbaası, Ankara 1888.

Düstur 1/6, "Mekteb-i Mülkiye-i Şahaneden Neşet Edipte Taşra Memuriyetini Kabulden İstinkaf Edenler Hakkında Olunacak Muameleye Dair Nizamname", Devlet Matbaası, Ankara 1893.

Düstur 1/6, "Usul-i İntihab-1 Memurin-i Adliye Kanununa Tezyil Edilmek Üzere Kaleme Alınan Mevaddı Kanuniye", Devlet Matbaası, Ankara 1893.

Düstur 1/8, "Mekteb-i Mülkiye-i Şahane Mezunlarının Maiyet Memuriyetleriyle Kaza Kaymakamlıklarına Tayinleri Emrinde Müttehaz Usul Hakkında İrade-i Seniye”, Başvekalet Devlet Matbaası, Ankara 1905.

Düstur 1/8, "Memurin-i Rüsumiyenin Usulü İntihabiyesi Hakkında Nizamname", Başvekalet Devlet Matbaası, Ankara 1906.

Düstur Zeyl 3, “Memurin-i Mülkiye Terakki ve Tekaüd Kararnamesi”, 1881.

Gözler, Kemal and Kaplan, Gürsel, İdare Hukuku Dersleri, Ekin, Bursa 2015.

Güler, Birgül Ayman, Kamu Personeli: Sistem ve Yönetim, İmge, Ankara 2005.

Hamid, Hukuk-ı Esasiye ve İdare Dersleri, Matbaa-i Amire, İstanbul 1331.

İbrahim Hakkı, Hukuk-ı İdare, Karabet Matbaası, İstanbul 1312.

Kasap, Sevilay, “Osmanlı Merkez Bürokrasisinde Gayrimüslimlerin İstihdamı (1839-1876)”, Yayımlanmamış DT, Marmara Üniversitesi, SBE, İstanbul 2011.

Kemalpaşazade Said, Hukuk-ı Siyasiye-i Osmaniye, Alemdar Matbaası, İstanbul 1329.

Kılıç, Musa, “Tanzimat Döneminde Osmanlı Hariciye Nezareti'nin Ermeni Memurları”, Ankara Üniversitesi Dil ve Tarih-Coğrafya Fakültesi Tarih Bölümü Tarih Araştırmaları Dergisi, 
Volume: 31, Issue: 51, 2012, pp. 93-124.

Kırmızı, Abdülhamit, "Osmanlıcılık Bürokrasisinde Gayrimüslim İstihdamı", Divan İlmi Araştırmalar, Issue: 13, 2002, pp. 295-306.

Konan, Belkıs, "Gayrimüslim Osmanlı Vatandaşlarının Hukuki Durumuna İlişkin Bir Değerlendirme", Ankara Üniversitesi Hukuk Fakültesi Dergisi, Volume: 64, Issue: 1, 2015, pp. 171-93.

Kuzu, Burhan, Türk Anayasa Metinleri ve İlgili Mevzuat, Filiz, İstanbul 1988.

Ömer Ziyaeddin, Mirat-ı Kanun-ı Esasi. Saika Matbaası, İstanbul 1324.

Özkorkut, Nevin Ünal, “1876 Anayasası'nın Hukuk Devleti Unsurları Açısından Osmanlı Devlet Anlayışına Getirdiği Yenilikler", Ankara Üniversitesi Hukuk Fakültesi Dergisi, Volume: 53, Issue: 1, 2004, pp. 173-84.

Prime Ministerial Ottoman Archive (BOA), Cevdet Health Documents (C.SH), 25/1202, 4.3.1840; Foreign Ministry Political Affairs (HR.SYS), 2926/5, 14.11.1852; Foreign Ministry's Translation Bureau (HR.TO), 165/76, 20.11.1895; Interior Ministry Correspondence Office (DH.MKT), 2425/121, 7.11.1900; Interior Ministry Office of Encoding Documents (DH.ŞFR), 219/53, 26.12.1897; Police and Security Documents (ZB), 112/4, 2.9.1890; Sadaret (Prime Ministry) All Provinces Documents (A.MKT.UM), 557/38, 22.4.1862; Ylldiz Palace General Documents (Y.PRK.UM), 35/55, 11.8.1896.

Tanör, Bülent, Osmanll-Türk Anayasal Gelişmeleri (1789-1980), Yapı Kredi, İstanbul 2017.

Türk Hukuk Lugati, Türk Hukuk Kurumu, Ankara 1991.

Uyanık, Ercan, “Tanzimat Dönemi’nde (1839-1876) Yönetim Yapısı” in Türk İdare Tarihi, ed. Erkan Tural, Anadolu Üniversitesi, Eskişehir 2013. 